$\left.\begin{array}{l}\text { Sournals } \\ \text { INTERNATIONAL JOURNAL OF } \\ \text { ORGANIZATIONAL LEADERSHIP }\end{array}\right) \begin{gathered}\text { INDUSTRIAL } \\ \text { MANAGEMENT } \\ \text { INSTITUTE }\end{gathered}$

\title{
A model for identification of informal groups' leaders
}

\author{
Alireza Bafandeh Zendeh*, Hamed Saghafi Oskuie \\ Department of Management, Tabriz branch, Islamic Azad University, Tabriz, Iran
}

\begin{tabular}{l}
\hline \\
Keywords: \\
Social Influence, \\
Informal Leaders, \\
Dematel Technique, \\
AHP Method \\
\hline Received \\
09 April 2016 \\
Received in revised form \\
23 December 2016 \\
Accepted \\
01 January 2017 \\
\hline
\end{tabular}

Abstract

Correspondence:

Bafandeh@iaut.ac.ir

\begin{abstract}
The main purpose of this research is to develop a way for identification of informal leaders in the organizations by Dematel technique. For this purpose, firstly the components of social influence of informal leaders in the organizations have been identified based on the review of the related literature. Using the idea of masters and pundits in psychology, management, and exploitation of Analytic Hierarchy Process (AHP), we identified the local weight of social influence criterions of informal leaders. Finally, by calculating inconsistency rate, the reliability of criterions' pairwise comparisons was approved. After this stage, a questionnaire was prepared to calculate the measure of social influence of spastic sample and was delivered to participants. By the use of scores obtained from questionnaire and Dematel technique, participants ranked on the basis of the highest social influence.
\end{abstract}

\section{Introduction}

It has long been accepted as fact that good leadership has a vital role in commerce, government orders, groups, and organizations that shape our lives or the environment that we work in. If leadership is considered as an important element, the central problem will be that what criteria a person needs in order to change to a great leader. To this end, leadership is considered as the ability to dominate a group and lead them in the way of expected purposes (Pescosolido, 2001). The source of this power or dominance has both formal and informal aspects but nonorganizational or informal leadership may be more important than formal power or dominance (Clugston, 2000). Leaders provide sufficient information for group members and have the 
ability of processing the remarkable part of this information which leads to the consistent and united decisions of that group. The study of group behavior has a long history among social science scientists. In the late $1920 \mathrm{~s}$, managers recognized that they need to know how the relations between members of a group affect their behavior. When the pioneers of organizational scientists aimed to improve the performance through the change of working conditions, they found that such a performance is assigned by informal groups and not by management policies (Cialdini et al., 1975). Studies related to the human relation ideology led to the discovery of informal groups and relations among members of an organization. These relations were different with formal relations and sometimes they were not related to the goals of the organization. Informal organization is an individual tie in the organization which has some effects on decisions but it does not exist in the formal design or itis incompatible with that design (Asch,1956). There is a belief that informal organizations are considered as a network of individual and social relations that necessarily are not formed by organization but they exist in an impulsive way by association and interaction between people.

\section{The Literature Review}

\section{Characteristics of Informal Organizations}

Informal organizations have certain characteristics: They are made on the basis of people's inner intentions and we cannot revoke them by official guidelines; despite formal organizations, they are small and limited; authorities in it are based upon trust not hierarchy and jobs; and leaders of informal organizations are selected by some criteria such as personality, moral penetration, capability, and old age (Asch, 1956).

Among these informal groups, people have a special popularity in the group and are accepted by them and the others follow them; these persons are called informal leaders. Informal leaders are like glorious leaders and such a leader has a power that can attract his followers. These followers devote themselves to their goals and are proud of having such leader and their honor is sacrificing in the way of preparation of leader's goals and expected mission (Moorhead \& Grifin, 1989).

The condition of sociometric tests is that the members of the group know each other; for this reason, this technique is used in small groups. This simple and also official tool has a lot of limitations. In the present article it is aimed to introduce a method to identify leader of each member on the basis of social penetration measure of each member on the others by the use of a math tool (Dematel). Social penetration requires a person or group to take advantage of his/her social penetration to change others' attitudes or behaviors. Social power is a force that amenable person has to make expected changes. Social penetration is one of socio-psychology trends (Galbraith, 1983). The stated method in this article against some other methods such as sociogram has some accounting and mathematical aspects.

Social penetration of the informal leader is one of the factors that leads to the penetration of leaders among the members of informal groups. Social penetration consists of change in thoughts, sense, personal attitudes, and behaviors that helps to have relationship with other people or groups.

Social influence happens when one's emotions, opinions or behaviors are influenced by others. Social influence takes many forms and can be noticed 
in conformity, socialization, peer pressure, obedience, leadership, persuasion, sales and marketi ng. In 1958, Harvard psychologist, Herbert Kelman recognized three wide varieties of social influence, namely compliance, identification, and internalization. Compliance refers to the time that people seem to agree with others, but in fact keep their adverse opinions private; identification is when people are affected by someone who is admired and appreciated such as a popular celebrity; and internalization alludes to a time that people affirm a belief or behavior and agree both publicly and privately.

Morton Deutsch and Harold Gerard reported two psychological needs that guid humans to behave according to the assumptions of others. These involve our need to be right (informational social influence) and our need to be liked (normative social influence) (Mugny, Souchet, Codaccioni, \& Quiamzade, 2008). Informational influence (or social proof) refers to an impact to accept information from another as confirmation about reality. Informational influence has an effect when people are unsure, either because stimuli are mostly unclear or because there exists social disagreement. Normative influence is an effect to answer to the positive expectations of others. In terms of Kelman's typology, normative influence leads to public compliance, whereas informational influence leads to private acceptance (Blass, 2004).

French and Raven (1959) believe that change factor does not include guest persons and groups but includes norms and roles. Myers (1999) describes social influence as knowledge of understanding and expression effectiveness of thoughts, senses, and people's behaviors from other person's real, unreal or implied presence.

Effective management is a power that is applied masterly to access important purposes and decisions. There are a lot of researches about social influence and its components. For example, Clugston (2000) in his study about application of social influence's components in the social services and private and public organizations studied 207 institute. Results of the research about these three organizations showed that among three organizations, employees of the governmental organization took advantage of the components. People participate in the problems not just because of monetary profits, but they become active according to factors of social influence. It is stated that principles of decision making depend upon social influence factors and the effect of influence components lead to increasing of the effectiveness (Myres, 1999).

\section{Efficacious Factors of Influence}

Power is a potential element of penetration in others; also, penetration and leadership are obedient to power. Power refers to the ability of coercion to compliance and capability to do a work and make a result. This word is synonym to concepts such as control, power, command, dominance, and legal authority. Power idiomatically consists of potential ability of making changes in others. In these descriptions, power is defined as a potential power that may an individual have it but he/she may not reveal it. According to the most of pundits, the new attitude of power concept into a modern thought begins with viewpoints of Thomas Hobbes. $\mathrm{He}$ is introduced as a main designer of modern political thought in the context of power (French \& Raven, 1959).

\section{Definition of Power}


According to Toffler (1990), power refers to the ability of preparation and use of violence, wealth, wisdom or their derivatives to encourage people in our expected ways which can satisfy our needs and tendencies. Following this, there are three sources of power including personality, ownership and organization.

Personality: Personality leads to access power. These sources overlap with each other. Each source with special tools has a strong relation but not exclusive. Organization with satisfactory power, ownership with encouraging power and personality with punitive power has old and central relations. The most important factor attached to personality in the modern communities is a relation between it and satisfactory power. There are different aspects in personality that has a relation with satisfactory power such as person's ability to say his/her thought in a persuasive way. Having straight belief, deep faith, and wording trenchant.

Ownership: In fact, ownership is one of the three power sources. Recently, its importance has been decreased in comparison to organization power which arises from ownership and actually from monetary sources in the commerce institutes and government. Access to power tools by ownership has been decreased. Indeed, ownership simplified accessing to satisfactory power. In the past especially in last years of previous century, validity and ownership was so much that without need to paying reward, it dedicated power to its owner. Wealth had a good fame and could obtain both encouragement and satisfactory powers.

Organization: Organization is powerful when it has effective access to all three power and it is weak when its effect is low or there is no effect. If an organization accesses to ownership and personality, it is clear that it can come to power by this relation and if it has authority to take advantage of these powers in different grades, its power will be increased. Researchers have classified social power (Shukla 1982). Among these French and Raven (1959) divided social power to some classes and on the basis of this classification, they recognized five different origins to power, namely reward power, coercive power, legitimate or legal power, charisma or referent power, and expert power.

Reward power consists of ability to prepare things that people like to have them. This power is measured by persons' control on rewards which are valuable to others. For example, most important organizational rewards are salary, promotion, and mission mitigation.

Coercive or force power is made when a person has the ability of coercion or bodily or mental damage to the others. Therefore, it can be said this power is based upon staff's fear and terror and its origin is fear and horror.

Regarding Legal or legitimate power, thinkers in different references about management, considered legal and legitimate power as on united case, but some considered them as separate cases and described them separately. People, who describe these two powers as a united case, indicate that limitations of this legal right are recognized by formal nature of organizational authority and also by informal norms and traditions.

Legal power results from organizational position and relies on people's formal position. So, people who can have coworker because of their formal authorities, have legal power. Legal power may be positive or negative in people. Positive legal power is concentrated on job 
performance creatively but negative legal power is threatening and contemptuous and its main goal is to satisfy selfishness of officer (Clugston, 2000). Therefore, source of this power is organization and the measure of legal power is changed by kind of organization.

Legitimate power arises from social norms and values. This kind of power consists of the right of decision making about cases that the staff consider it in leader's dignity (Clugston, 2000).

\section{Charisma or Referent Power}

Referent power consists of person's perception from interaction's attraction with a special man. When staff attributes some good features such as trust, honesty, and discretion to their boss, we can say that boss has authority power (French \& Raven, 1959). This power mainly arises from person. If a person is an honor man from another person's view, so he can use his power to that person. In some cases, referent power is similar to charisma. Especially, referent power is associated with trust, similarity, acceptance, kindness, emulation, and mental ownerships. Charisma is one of the personality characteristics and one of the penetration ways in a person or group. Charismatic persons can attract people mass to them and force them to do some works and those people do not consider it as injustice. A charismatic person can affect others' behavior. In traditional societies, charisma is related to unusual features but many sociologists believe it is possible to find a charismatic personality and can learn the charismatic personality features (Lee \& Low, 2010).

\section{Expert Power}

Expert power consists of ability to control others' behavior by knowledge, experience or judgment that he does not have but needs it (French \& Raven, 1959). This power can appear in different organizational positions. Other features of effective leaders are eloquence skill, vast knowledge, and social and physical attraction; it means that people can play the role of leadership in the organization who has mentioned characters because leaders who have eloquence skills can state their viewpoints in an acceptable way. Word attraction, beauty, attraction of physical characters such as height, face, and body movements and also social characters such as social and political position are the factors of increasing leader's penetration. Numerous researches argued that following advice and techniques can facilitate and accelerate others' penetration, influence, and satisfaction:

It is claimed that individual validity which intends to influence on others, facilitates their encouragement too. Validity is subject to specialty, trust, attraction, and popularity. Similarity between parties of a leadership such as effectiveness relation accelerates the process of penetration. Researches state that Blacks children accept Black dentists' advices about mouth and teeth health more than white dentists. Specialty is another factor which refers to having knowledge and specialized and technical information, especially if it is exclusive and rare. And, into the high technology, dynamic, and active organizations it is the main source of power. In these organizations, having specialties and target information of organization makes people powerful.

In terms of individual attractiveness and popularity, people who have acceptable behavior and elegant and attractive appearance have a main source of power. The reason of using 
attractive, elegant, and favored persons in commercial advertisements relates to their power and penetration. There are a lot of documents that show people with acceptable personalities are more effective than unacceptable personalities.

\section{Efficacious Factors on Penetrance}

Factors leading to people's penetrability are conformity, compliance, and compliance to authority. Each one will be explained briefly. Conformity is a change in behaviors or believes of people because of groups or society's indirect pressure. Compliance is a change that appears in a person's behavior by others direct request. Obeying the referent power is a kind of social penetration in which person obeys others' orders (Hall, 1991).

According to Asch's (1956) experiments to find the reasons of conformity with others, it can be said that main factors of conformity are informational conformity (person prefers others' vote to his/ her vote) and normal conformity (person prefers others vote because of escaping from negative results of disagreement with others and assessment to positive results).

Cialdini et al. (1975) noticed that the best way to study compliance and its techniques is considering the method of people performance that their success from monetary view or other's view depends on ability to excite others to respond to their requests. Politicians, merchants, owners of commercial companies, and different sellers are among these persons.

Cialdini et al. (1975) concluded that though people use different techniques to excite others to compliance, they are based on following elements in structural principles:

- The origin of friendship and kindness: We accept our relatives' requests more than strangers and persons that we do not love them.

- The origin of liability and harmony: If we have the sense of liability to a viewpoint, we prefer to follow person's requests to do works which are coordinate with that viewpoint.

- The sense of owing: We follow people's request that help us or give an advantage to us. In other words, we feel to do something because of others help (Asch, 1999).

\section{Obedience to Authority}

All of us must obey some power symbols such as parents, police, and traffic light; but in some cases obeying referent powers persuade us to behave against our beliefs. Compliance factors of referent power include social norms and gradual increase of duty (Hall, 1991).

\section{Method}

The study implemented descriptive method using qualitative data. The tools of data collection in primary stages of the research involved interview with reporters and pundits in the course of management and psychology to recognize main components of leadership and social influence. In text stage, a questionnaire was delivered to the samples to measure people's social influence on each other. In order to analyze the data with regard to their nature, the method of analyzing group decision making and Dematel technique came into use. Identifying the criteria of social influence was undertaken by studying books and articles about management and psychology and discussing with masters in psychology. 
In recognizing the criteria by using of group AHP technique, after identifying main criteria, importance degree of each criterion is considered through the ideas of 3 masters in psychology by group AHP.

In identifying the measure of people's social influence on each other, each person who completed the questions could estimate the opposite party s social influence in comparison to his/herself. Questionnaires in this research are emphasized based on 4 experts views in management and psychology. Their durability is analyzed by repeated test method and solidarity index between two tests has been obtained in 10-69 days.

The sample of the study was consisted of 19 staff of 4 organizational units in Tabriz industrial management organization and because in each organization, each person's social influence was compared with other members. The statistic samples are shown in Table 1.

Table 1

Research Sample Society

\begin{tabular}{lcc}
\hline Unit & Number of Sampler & Number \\
\hline Research and Consultation & 12 & 4 \\
Education & 56 & 8 \\
Accountancy & 12 & 4 \\
Patronage & 12 & 3 \\
Total & 86 & 19 \\
\hline
\end{tabular}

Identifying questionnaire grades and people's social influence on each other are classified by Dematel technique based upon the most social influence and a person who has the most influence are considered as group's informal leader.

\section{Results}

Identifying main criteria of social influence to carry out library studies and views of psychology experts and specialists, the overall factors of social influence can be shown in Figure 1.

\section{Identifying Importance Degree of Criteria by Group AHP Technique}

After identifying criteria of social influence, a pairwise comparison between these criteria is made to recognize relative weight of indices. Criteria of legal power, coercing power, and reward power because of formal nature of these powers are not considered into the double comparisons. Figure 2 presents AHP measure. 


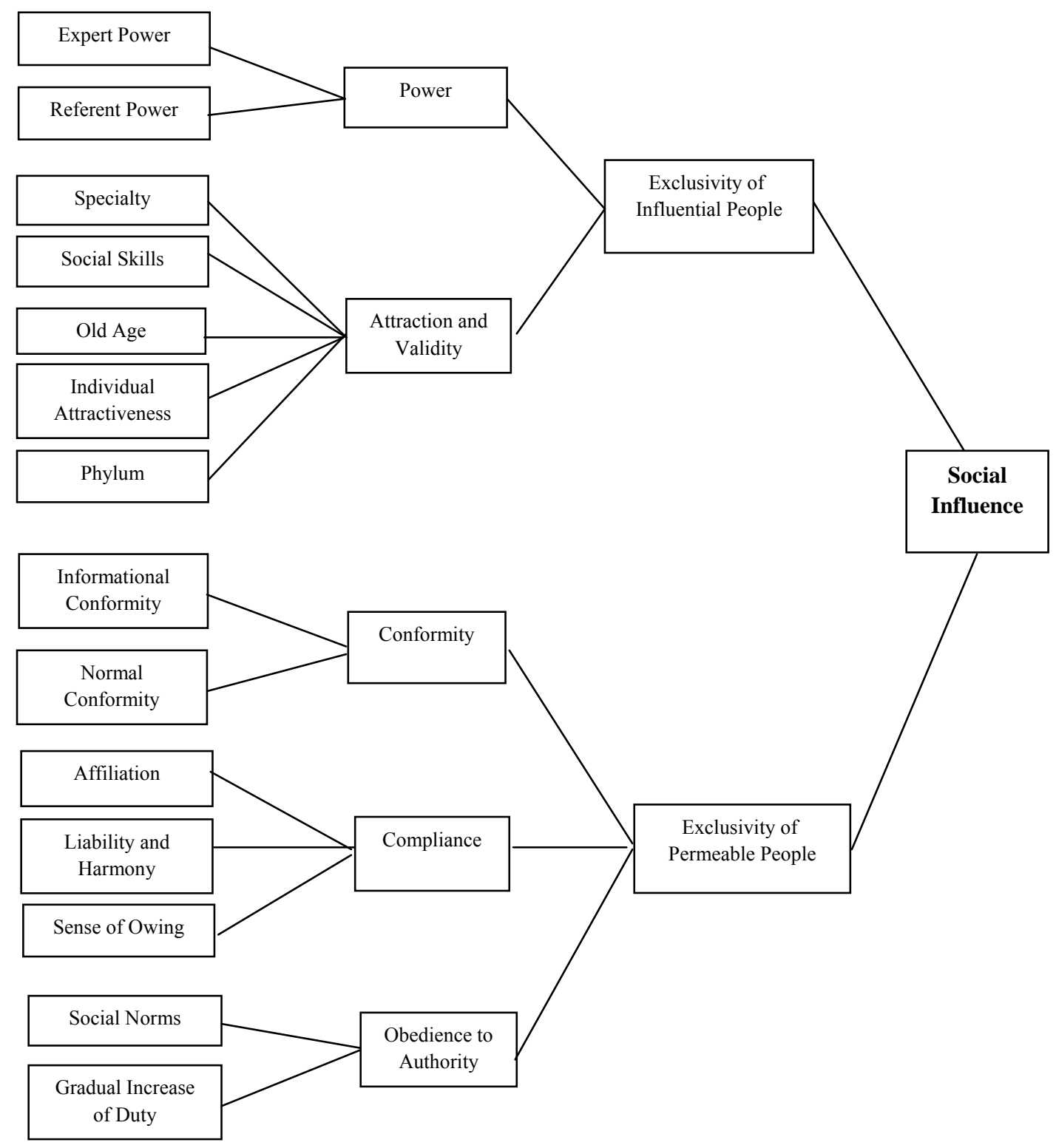

Figure 1. Criteria of social influence

Delineation

Two members have the same importance A member has preference than another A member has more preference than another A member has lots preference than another A member has too preference than another

\begin{tabular}{|c|c|}
\hline Degree of dimension & Define \\
Same Distinction & 1 \\
Low Distinction & 3 \\
More Distinction & 5 \\
Lots Distinction & 7 \\
Too Distinction & 9 \\
\hline
\end{tabular}

Figure 2. AHP measure

Table 2 represents the pairwise comparison of criteria of social influence. 
Table 2

Pairwise Comparison of Criteria of Social Influence

\begin{tabular}{lcc}
\hline Social Influence & Exclusivity of Influential People & Exclusivity of Permeable People \\
\hline Exclusivity of influential people & 1 & 1.26 \\
Exclusivity of permeable people & 0.74 & 1 \\
Total & 1.74 & 2.26 \\
\hline
\end{tabular}

For example, number 1.26 in Table 2 shows the experts to identify the preference of "features of effective pardons" to "features of amenable ones".

Table 3 shows the pairwise comparison of exclusivity of influential people.

Table 3

Pairwise Comparison of Exclusivity of Influential People

\begin{tabular}{lcc}
\hline Exclusivity of Influential people & Power & Attraction and Validity \\
\hline Power & 1 & 2.22 \\
Attraction and Validity & 0.43 & 1 \\
Total & 1.43 & 3.28 \\
\hline
\end{tabular}

Table 4 exhibits the pairwise comparison of exclusivity of influential people.

Table 4

Pairwise Comparison of Power

\begin{tabular}{ccc}
\hline Exclusivity of Influential people & Expert Power & Referent Power \\
\hline Expert Power & 1 & 3.29 \\
Referent Power & 0.30 & 1 \\
Total & 1.30 & 4.29 \\
\hline
\end{tabular}

Table 5 clearly indicates the pairwise comparison of attraction and validity.

Table 5

Pairwise Comparison of Attraction and Validity

\begin{tabular}{cccccc}
\hline Attraction and Validity & Specialty & Social Skills & Old Age & $\begin{array}{c}\text { Individual } \\
\text { Attractiveness }\end{array}$ & Phylum \\
\hline Specialty & 1 & 0.20 & 0.50 & 0.500 & 1.99 \\
Social Skills & 4.99 & 1 & 2.99 & 1.99 & 3.99 \\
Old Age & 1.99 & 0.33 & 1 & 0.50 & 1.99 \\
Individual Attractiveness & 1.99 & 0.50 & 1.99 & 0.33 & 2.99 \\
Phylum & 0.50 & 0.04 & 0.50 & 4.33 & 1 \\
Total & 10.49 & 0.08 & 6.99 & & 11.98 \\
\hline
\end{tabular}

Table 6 presents the pairwise comparison of exclusivity of permeable people.

Table 6

Pairwise Comparison of Exclusivity of Permeable People

\begin{tabular}{cccc}
\hline Exclusivity of Permeable People & Conformity & Compliance & Obedience to Authority \\
\hline Conformity & 1 & 6.30 & 6.63 \\
Compliance & 0.14 & 1 & 0.58 \\
Obedience to Authority & 0.14 & 1.70 & 1 \\
Total & 1.29 & 9.01 & 8.52 \\
\hline
\end{tabular}

Table 7 represents the pairwise comparison of conformity. 
Table 7

Pairwise Comparison of Conformity

\begin{tabular}{lcc}
\hline Conformity & Informational Conformity & Normal Conformity \\
\hline Informational Conformity & 1 & 0.79 \\
Normal Conformity & 1.26 & 1 \\
Total & 2.26 & 1.79 \\
\hline
\end{tabular}

Table 8 shows the pairwise comparison of compliance.

Table 8

Pairwise Comparison of Compliance

\begin{tabular}{lccc}
\hline Compliance & Affiliation & Liability and Harmony & Sense of Owing \\
\hline Affiliation & 1 & 2.99 & 0.50 \\
Liability and Harmony & 0.33 & 1 & 0.33 \\
Sense of Owing & 1.99 & 2.99 & 1 \\
Total & 3.33 & 6.99 & 1.83 \\
\hline
\end{tabular}

Table 9 exhibits the pairwise comparison of obedience to authority.

Table 9

Pairwise Comparison of Obedience to Authority

\begin{tabular}{lcc}
\hline Obedience to Authority & Social Norms & Gradual Increase of Duty \\
\hline Social Norms & 1 & 1.58 \\
Gradual Increase of Duty & 0.63 & 1 \\
Total & 1.63 & 2.58 \\
\hline
\end{tabular}

\section{Normalizing Matrix of Pairwise Comparisons and Calculate Relative Weight of Indices}

After defining pairwise comparisons of matrix by dividing each element by all of target column, we normalized the numbers and in order to calculate the relative weight of indices, we calculated the logical average of each index. Table 10 presents the normalized matrix and relative weight of criteria of social influence.

Table 10

Normalized Matrix and Calculate Relative Weight of Criteria of Social Influence

\begin{tabular}{lcccc}
\hline Social Influence & Exclusivity of Influential People & Exclusivity of Permeable People & Total & Arithmetic Average \\
\hline $\begin{array}{l}\text { Exclusivity of Influential } \\
\text { People }\end{array}$ & 0.55 & 0.55 & 1.11 & 0.55 \\
$\begin{array}{l}\text { Exclusivity of Permeable } \\
\text { People }\end{array}$ & 0.44 & 0.44 & 0.88 & 0.44 \\
Total & 1.0 & 1.0 & & 1 \\
\hline
\end{tabular}

Table 11 represents the normalized matrix and relative weight of exclusivity of influential people.

Table 11

Normalized Matrix and Calculate Relative Weight of Exclusivity of Influential People

\begin{tabular}{lcccc}
\hline Exclusivity of Influential People & Power & Attraction and validity & total & Arithmetic average \\
\hline Power & 0.69 & 0.69 & 1.39 & 0.69 \\
Attraction and Validity & 0.30 & 0.30 & 0.60 & 0.30 \\
Total & 1.0 & 1.0 & & 1 \\
\hline
\end{tabular}


Table 12 exhibits the normalized matrix and relative weight of power.

Table 12

Normalized Matrix and Calculate Relative Weight of Power

\begin{tabular}{lcccc}
\hline Power & Expert Power & Referent Power & Total & Arithmetic Average \\
\hline Expert Power & 0.76 & 0.76 & 1.53 & 0.76 \\
Referent Power & 0.23 & 0.23 & 0.46 & 0.23 \\
Total & 1.0 & 1.0 & & 1 \\
\hline
\end{tabular}

Table 13 shows the normalized matrix and relative weight of attraction and validity.

Table 13

Normalized Matrix and Calculate Relative Weight of Attraction and Validity

\begin{tabular}{lccccccc}
\hline $\begin{array}{l}\text { Attraction and } \\
\text { Validity }\end{array}$ & Specialty & Social Skills & Old Age & $\begin{array}{c}\text { Individual } \\
\text { Attractiveness }\end{array}$ & Phylum & Total & $\begin{array}{c}\text { Arithmetic } \\
\text { Average }\end{array}$ \\
\hline Specialty & 0.09 & 0.096 & 0.07 & 0.11 & 0.16 & 0.54 & 0.10 \\
Social Skills & 0.47 & 0.480 & 0.42 & 0.46 & 0.33 & 2.17 & 0.43 \\
Old Age & 0.19 & 0.160 & 0.14 & 0.11 & 0.16 & 0.77 & 0.15 \\
Individual & 0.19 & 0.240 & 0.28 & 0.23 & 0.25 & 1.19 & 0.24 \\
Attractiveness & 0.04 & 0.023 & 0.07 & 0.07 & 0.08 & 0.30 & 0.06 \\
Phylum & 1.0 & 1.0 & 1.0 & 1.0 & 1.0 & & 1 \\
Total & & & & & & & \\
\hline
\end{tabular}

Table 14 presents the normalized matrix and calculate relative weight of exclusivity of permeable people.

Table 14

Normalized Matrix and Calculate Relative Weight of Exclusivity of Permeable People

\begin{tabular}{lccccc}
\hline Exclusivity of Permeable People & Conformity & Compliance & Obedience to Authority & Total & Arithmetic Average \\
\hline Conformity & 0.77 & 0.69 & 0.77 & 2.25 & 0.75 \\
Compliance & 0.11 & 0.11 & 0.06 & 0.29 & 0.10 \\
Obedience to Authority & 0.11 & 0.19 & 0.11 & 0.41 & 0.14 \\
Total & 1.0 & 1.0 & 1.0 & & 1 \\
\hline
\end{tabular}

Table 15 clearly indicates the normalized matrix and relative weight of conformity.

Table 15

Normalized Matrix and Calculate Relative Weight of Conformity

\begin{tabular}{lcccc}
\hline Conformity & Informational Conformity & Normal Conformity & Total & Arithmetic Average \\
\hline Informational Conformity & 0.44 & 0.44 & 0.88 & 0.44 \\
Normal Conformity & 0.55 & 0.55 & 1.11 & 0.55 \\
Total & 1.0 & 1.0 & & 1 \\
\hline
\end{tabular}

Table 16 shows the normalized matrix and relative weight of compliance.

Table 16

Normalized Matrix and Calculate Relative Weight of Compliance

\begin{tabular}{lccccc}
\hline Compliance & Affiliation & Liability and Harmony & Sense of Owing & Total & Arithmetic Average \\
\hline Affiliation & 0.30 & 0.42 & 0.27 & 1.00 & 0.33 \\
Liability and Harmony & 0.10 & 0.14 & 0.18 & 0.42 & 0.14 \\
Sense of Owing & 0.60 & 0.42 & 0.54 & 1.57 & 0.52 \\
Total & 1.00 & 1.00 & 1.00 & & 1 \\
\hline
\end{tabular}


Table 17 exhibits the normalized matrix and relative weight of obedience to authority.

Table 17

Normalized Matrix and Calculate Relative Weight of Obedience to Authority

\begin{tabular}{lcccc}
\hline Obedience to Authority & Social Norms & Gradual Increase of Duty & Total & Arithmetic Average \\
\hline Social Norms & 0.61 & 0.61 & 1.22 & 0.61 \\
Gradual Increase of Duty & 0.38 & 0.38 & 0.77 & 0.38 \\
Total & 1.00 & 1.00 & & 1 \\
\hline
\end{tabular}

\section{Measure of People's Social Influence by Dematel Technique}

Final questionnaire includes information about social influence of a person to other members of group. By this information it has shown the measure of people's effect on each other. The main goal of classifying social influence is done by Dematel technique.

Table 18 represents the measure of social influence to each others. A, B, C, D are indicative names of persons.

Table 18

Measure of Social Influence to Each Others

\begin{tabular}{ccccc}
\hline Research and Consultation Unit & A & B & C & D \\
\hline A & 0 & 3.24 & 2.52 & 0.84 \\
B & 1.77 & 0 & 1.04 & 1.65 \\
C & 1.20 & 0.56 & 0 & 0.63 \\
D & 2.71 & 3.36 & 2.43 & 0 \\
\hline
\end{tabular}

In Table 18, in first line of third column 3.24 is a value which is obtained by final questionnaire of person A in comparison to person B. In fact, social influence of A to B is 3.24. Another numbers are calculated in this way. Figure 2 illustrates the model and measure of social influence to each other. At last a member who has the most influence to the other members, can be chosen as informal leader.

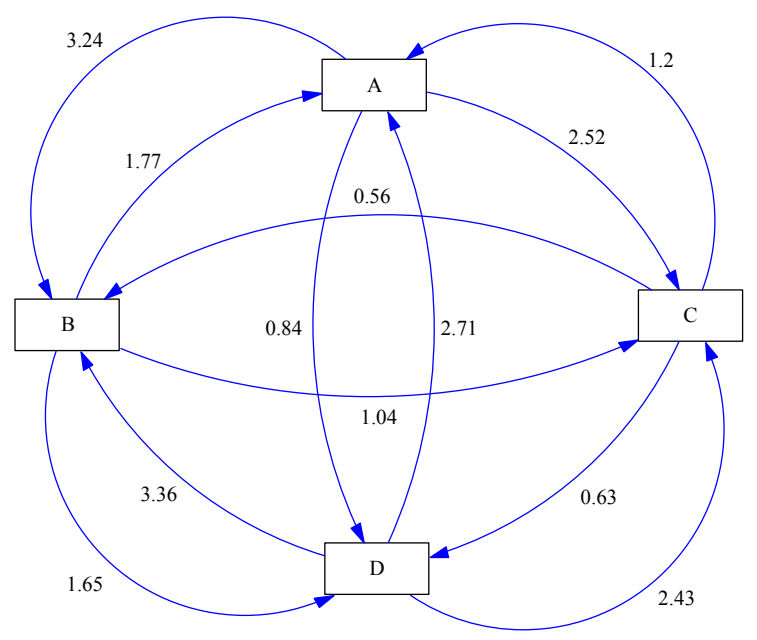

Figure 2. Measure of social influence to each others 
Each line of $\widehat{M}$ matrix is multiplied by the reverse of the line total $(\alpha)$ of that matrix, and the result is shown as $\mathrm{M}$ matrix.

$\mathrm{M}=\alpha . \widehat{M} \alpha=\frac{1}{8.521}=.177$

Table 19 indicates the measure of straight relations.

Table 19

Measure of Straight Relations

\begin{tabular}{cccccc}
\hline Research and Consultation Unit & A & B & C & D \\
\hline A & 0 & 0.37 & 0.29 & 0.09 \\
B & 0.20 & 0 & 0.12 & 0.19 \\
C & 0.14 & 0.06 & 0 & 0.07 \\
D & 0.31 & 0.39 & 0.28 & 0 \\
\hline
\end{tabular}

Now we can calculate matrix $\mathrm{M}(\mathrm{I}-\mathrm{M})^{-1}$ and obtain present relative intensity from direct and indirect relations between people of unit which is shown in Table 20.

Table 20

$M(I-M)^{-1}$ Matrix, Measure of Direct Relations and Indirect Relations

\begin{tabular}{cccccc}
\hline Research and Consultation Unit & A & B & C & D & Line Total \\
\hline A & 0.30 & 0.66 & 0.54 & 0.29 & 1.78 \\
B & 0.42 & 0.31 & 0.37 & 0.32 & 1.44 \\
C & 0.25 & 0.23 & 0.14 & 0.15 & 0.79 \\
D & 0.65 & 0.78 & 0.64 & 0.26 & 0.23 \\
Column Tool & 1.64 & 1.98 & 1.71 & 1.03 & \\
\hline
\end{tabular}

According Table 20 we get rank of social influence of people represented in Table 21.

Table 21

Ranking of Social Influence of People

\begin{tabular}{cccccc}
\hline Order of Elements & $\begin{array}{c}\text { According the Most } \\
\text { Line Total (R) }\end{array}$ & Order of Elements & $\begin{array}{c}\text { According the Most } \\
\text { Column Total (J) }\end{array}$ & Order of Element & According (R-J) \\
\hline D & 2.35 & B & 1.98 & D & 1.32 \\
A & 1.78 & C & 1.71 & A & 0.13 \\
B & 1.44 & A & 1.64 & B & -0.53 \\
C & 0.79 & D & 1.03 & C & -0.92 \\
\hline
\end{tabular}

The most line total $(\mathrm{R})$ is the representative of the order of elements that have strong effects on the other elements and the most column total $(\mathrm{J})$ is representative of the order of elements which are amenable elements. The main place of each element is final hierarchy represented in column (J-R). If (R-J) is positive, so person absolutely is an effective element and if it is negative that person will be an amenable person. Therefore, persons "A" and "D" because of being positive measure (R-J) are effective persons and" B" and" C" because of being negative (R-J) are amenable persons in this unit. In the consulting and research unit, in column (R-J), "D" has the most value; it means that "D" has the most social influence on the other members. So, "D" is assigned as an informal leader of consulting and research unit. 


\section{Discussion and Conclusion}

Regarding the obtained results of Dematel technique to identify informal leaders in the informal groups, it has been indicated that we can identify informal leaders of the informal groups by comparing the component of people's social influence in comparison to each other and by classifying this component by Dematel technique. In the case study, a person with the most social influence in comparison to the other members is selected as informal leader of the informal group. Also, by calculating the importance of the index of social influence components, it is clear that criteria such as expert power, social skills, harmony, sense of owing, and social norm of obeying of referent power have the most importance and they have the main role in identifying informal leaders. Other components such as referent power, relationship ties, and friendship tie are in the next preferences of identifying informal leaders. There are other ways to consider interaction relations in the group such as sociometry. The study is limited since the method applied in the current study is time consuming and this feature is a limitation for mentioned method. In this research criteria to identify informal leaders have been considered separately; to this end, future research is necessary to consider the relation between these criteria. Also, other models of multi-criteria decision making (MCDM) can be used to classify the criteria.

\section{References}

Asch, S. E. (1956). Studies of independence and conformity: A minority of one against unanimous. Psychological Monographs, 70(9), 1-70.

Blass, T. (2004). The man who shocked the world: The life and legacy of Stanley Milgram. New York: Basic Books.

Cialdini, R. B., Vincent, J. E., Lewis, S. K., \& Catalan, J., Wheeler, D., \& Darby, B. L. (1975). Reciprocal concessions procedure for inducing compliance. Journal of personality \& Social Psychology, 31, 206-215.

Clugston, M. (2000). The mediating effects of multidimensional commitment on job satisfaction and intent to leave. Journal of Organizational Behavior, 21(4), 477-486.

Daft, R. L. (1989). Organization theory and designs ( $3^{\text {rd }}$ ed.). New York: West Publishing Company.

Franzoi, S. L. (2003). Social psychology. New York: McGraw-Hill.

French, J. R. P., Jr., \& Raven, B. (1959). The bases of social power. In D. Cartwright (Eds.), Studies in social power (pp. 150167). Ann Arbor, MI: Institute for Social Research.

Galbraith, J. K. (1983). The anatomy of power. Boston: Houghton Mifflin.

Hall, R. H. (1991). Organizations, structures, processes, and outcomes. Englewood Cliffs, NJ: Prentice Hall.

Kelman, H. (1958). Compliance, identification, and internalization: Three processes of attitude change. Journal of Conflict Resolution, 1, 51-60.

Koontz, H., \& Weihrich, H. (1988). Management ( $9^{\text {th }}$ ed.). New York: McGrow-Hill.

Lee, K. L., \& Low, G. T. (2010). The influence of social power and educational orientation on the outcomes of superiorsubordinate dyadic relationship. European Journal of Social Sciences, 16(4), 588-606.

Moorhead, G., \& Grifin, R. W. (1989). Organizational Behavior. Boston: Houghton Miffin.

Myres, D. G. (1999). Social psychology. New York, NY: McGraw-Hill.

Mugny, G., Souchet, L., Codaccioni, C., \& Quiamzade, A. (2008). Représentations sociales et influence sociale. Psychologie Française, 53(2), 223-237.

Pescosolido, A. T. (2001). Informal leaders and the development of group efficacy. Small group research, 32(1), 74-93.

Shukla, R.K. (1982). Influence of power bases in organizational decision making: A contingent model.Decision Sciences, 13(3), 450-470.

Toffler, A. (1990). Powershift: Knowledge, wealth and violence at the edge of the 21st century. New York: Bantam Books. 